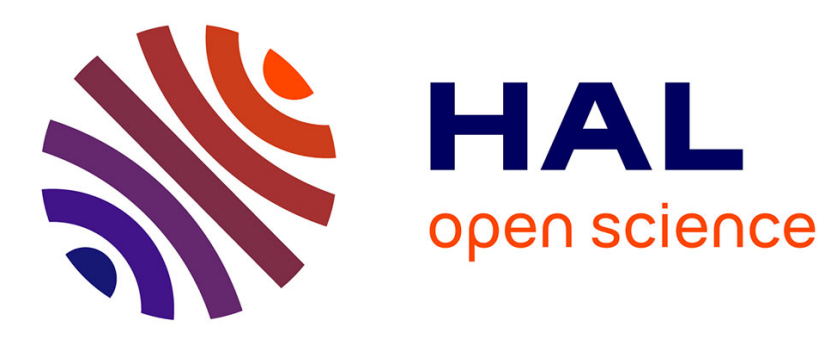

\title{
Nondestructive allometric model to estimate aboveground biomass: an alternative approach to generic pan-tropical models
}

Yehualashet Belete, Abere Fentahun, Birhanu Kebede, Teshome Soromessa

\section{- To cite this version:}

Yehualashet Belete, Abere Fentahun, Birhanu Kebede, Teshome Soromessa. Nondestructive allometric model to estimate aboveground biomass: an alternative approach to generic pan-tropical models. 2019 . hal-02265451

\section{HAL Id: hal-02265451 \\ https://hal.science/hal-02265451}

Preprint submitted on 9 Aug 2019

HAL is a multi-disciplinary open access archive for the deposit and dissemination of scientific research documents, whether they are published or not. The documents may come from teaching and research institutions in France or abroad, or from public or private research centers.
L'archive ouverte pluridisciplinaire HAL, est destinée au dépôt et à la diffusion de documents scientifiques de niveau recherche, publiés ou non, émanant des établissements d'enseignement et de recherche français ou étrangers, des laboratoires publics ou privés. 


\section{Journal of Environmental Studies and Sciences}

\section{Nondestructive allometric model to estimate aboveground biomass: an alternative approach to generic pan-tropical modelsNondestructive allometric model to estimate aboveground biomass: an alternative approach to generic pan-tropical models --Manuscript Draft--}

\section{Manuscript Number:}

Full Title:

Article Type:

Corresponding Author:
Nondestructive allometric model to estimate aboveground biomass: an alternative approach to generic pan-tropical modelsNondestructive allometric model to estimate aboveground biomass: an alternative approach to generic pan-tropical models

Original Article

Yehualashet Belete

Addis Ababa University College of Natural Sciences

ETHIOPIA

Corresponding Author Secondary

Information:

Corresponding Author's Institution:

Addis Ababa University College of Natural Sciences

Corresponding Author's Secondary Institution:

First Author:

Yehualashet Belete

First Author Secondary Information:

Order of Authors:

Yehualashet Belete

Order of Authors Secondary Information:

Funding Information:

Addis Ababa University

(Not applicable)

Mr. Yehualashet Belete

Abstract:

Biomass and carbon stock analysis and estimations are performed with the use of mathematical allometric models. Developing countries in Sub-Sharan Africa such as Ethiopia lack the expensive resources to develop such costly models destructively. As a result, they are left with the only option to adopt models formulated from unrelated geographic areas which usually bears error in estimation. This study estimates the biomass of indigenous trees and develop allometric model for the Egdu Forest located Oromia region, Ethiopia. Nondestructive sampling is used to collect samples where diameter at breast height $(\mathrm{DBH})$, local wood density $(\rho)$, and tree height $(\mathrm{H})$ are the estimator variable for total dry aboveground biomass (TAGB). Trees are selected based on DBH variability on the study site and located in a delineated area of quadrat plot. A set of species-specific models to relate AGB to estimator variables are fitted to the data. The allometric equation that fit the linear models has a significant $p$-value $(P<0.000)$. Model comparison and selection are based on the Akaike information criterion (AIC), adjusted coefficient of determination (R2) and residual standard error (RSE) of the regression. Comparison of our results with those obtained using generalized pan-tropical model revealed differences in biomass estimations. The developed equations can be used for greater accuracy by researchers, forest managers and/or organization like REDD+ to calculate aboveground biomass and carbon stock of the studied species in Ethiopia.

\section{Suggested Reviewers:}

Dr. Tulu Tora (PhD), Tora, PhD

Kotebe Metropolitan University, Addis Ababa, Ethiopia tulutollatura@gmail.com

Dr. Binyam Alemu, Alemu, PhD

Researcher, University of Eastern Finland, Finland

binyamalemu.2011@gmail.com 


\title{
Nondestructive allometric model to estimate aboveground biomass: an alternative approach to generic pan-tropical models
}

\author{
Yehualashet Belete $^{1 *}$ Fentahun Abere $^{2 \cdot}$ Birhanu Kebede $^{1} \cdot$ Teshome Soromessa $^{1}$ \\ ${ }^{1}$ Center for Environmental Science, Addis Ababa University, Addis Ababa, Ethiopia. \\ ${ }^{2}$ Department of Natural Resources Management, Debre Markos University, Gojjam, Ethiopia.
}

\begin{abstract}
:
Biomass and carbon stock analysis and estimations are performed with the use of mathematical allometric models. Developing countries in Sub-Sharan Africa such as Ethiopia lack the expensive resources to develop such costly models destructively. As a result, they are left with the only option to adopt models formulated from unrelated geographic areas which usually bears error in estimation. This study estimates the biomass of indigenous trees and develop allometric model for the Egdu Forest located Oromia region, Ethiopia. Nondestructive sampling is used to collect samples where diameter at breast height $(\mathrm{DBH})$, local wood density $(\rho)$, and tree height $(H)$ are the estimator variable for total dry aboveground biomass (TAGB). Trees are selected based on DBH variability on the study site and located in a delineated area of quadrat plot. A set of species-specific models to relate $A \mathrm{~GB}$ to estimator variables are fitted to the data. The allometric equation that fit the linear models has a significant p-value $(P<0.000)$. Model comparison and selection are based on the Akaike information criterion (AIC), adjusted coefficient of determination $\left(R^{2}\right)$ and residual standard error (RSE) of the regression. Comparison of our results with those obtained using generalized pan-tropical model revealed differences in biomass estimations. The developed equations can be used for greater accuracy by researchers, forest managers and/or organization like REDD+ to calculate aboveground biomass and carbon stock of the studied species in Ethiopia.
\end{abstract}

Keywords: Allometric model; Biomass; Species-specific; Egdu Forest; Nondestructive *Correspondence:YehualashetBelete Mengistu, E-mail: yehumen365@gmail.com, Mobile: +251909305778, Addis Ababa, Ethiopia. 


\section{Introduction}

Accurate estimation of biomass in tropical forests are lacking in many areas due to a lack of appropriate allometric models developed destructively for predicting biomass in species-rich tropical ecosystems, making estimations of the value of these species as carbon reservoir difficult (Chave et al.2005). This results in enormous uncertainty in the amount and spatial variations of aboveground biomass in Africa (Fayolle et al. 2013). In addition, the use of generalized biomass equations across a wider unrelated ecological location can lead to a bias and error in estimating biomass for a particular species and sites because species vary in wood specific gravity, tree sizes, and growth stage, and their accuracy is limited to the developed geographic areas (Henry et al. 2011 and Navar et al. 2002).

Moreover, applying direct destructive techniques for biomass estimation and develop allometric models are time-consuming, demand specialized labor and are very expensive (Houghton et al. 2001).In most cases such destructive studies are restricted to small trees for cost reasons and harvesting trees requires special authorization which is habitually difficult to acquire, and consequently only a few valid equations are available (Nath et al. 2009).Generic equations ignore key innate differences arising from species diversity and variation in species parameters such as local wood density as a main ecological trait(Nam et al. 2016). In addition, researchers argue that before pan-tropical allometric equations are used their validity within a particular geographic location needs to be tested (Crow 1978; Brown et al. 1989; Chave et al. 2001, 2005).

Conversely, the use of locally developed equations permits estimation of total aboveground biomass of a specific tree species as a composite of biomass components such as trunks, large branches, small branches, etc. (Djomo et al. 2010; FAO, 2012; Picard et al. 2012). Species-specific allometric equations estimate biomass based on locally measured tree variables such as height, diameter, wood density, and crown, etc. Advantage of such equations are explicit to species, sites, tree age and management (Kairo et al. 2009) and possess higher levels of accuracy and are becoming preferred means of biomass estimation in temperate and some tropical regions (Basuki et al.2009; Ketterings et al. 2001). This particular research estimated the biomass and developed a set of species specific allometric equations nondestructively and evaluated the biomass data against existing generic pan-tropical equation. 


\section{Materials and methods}

\section{Study site}

The study was conducted in Welmera District, Oromia regional state, central highlands of Ethiopia in a forest at about $30 \mathrm{~km}$ west of Addis Ababa and $5 \mathrm{~km}$ from Menagasha town to the south. Egdu Forest is one of the dry afromontane forests in central Ethiopia and ranges from 2,580 to 2,910 m above sea level. The forest covers a total area of 486ha (Adugna et al., 2013). The forest has a mean annual temperature of $17.1^{\circ} \mathrm{C}$ and mean annual rainfall of $1314 \mathrm{~mm}$ (EMSA, 2011). The dominant species in the study area are Bersama abyssinica Fresen, Cupressus lusitanica Mill, Maytenus arbutifolia Sebsebe, Rhamnus staddo A.Rich, were chosen for the study.

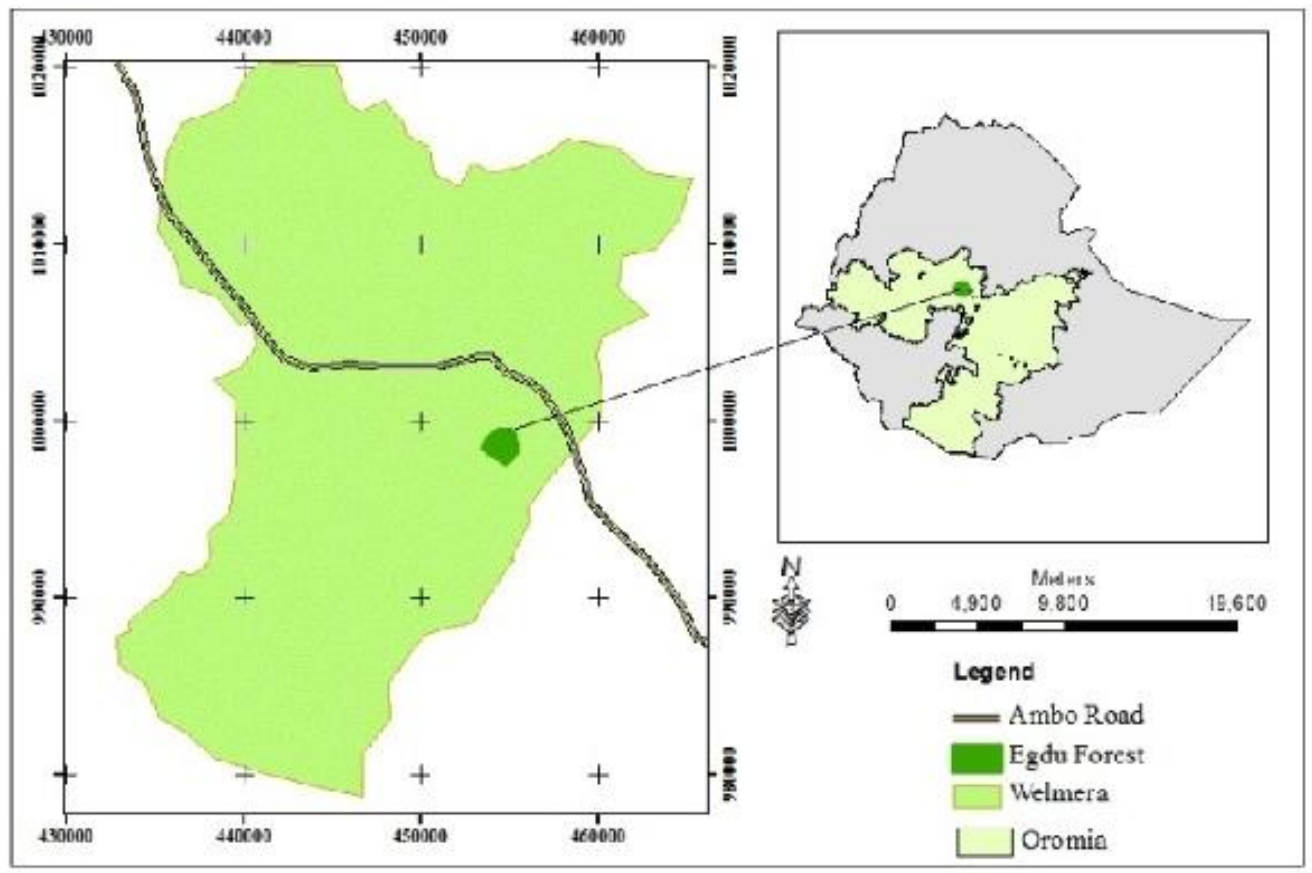

Fig.1. Location of study area in Ethiopia.

\section{Sampling method}

Preferential sampling was adopted because geographic location and the process being modeled are stochastically dependent (Diggle et al., 2010). After plots were established at the study site, preferential sampling was applied by starting a rapid screening of DBH class variability in the landscape, thereby delimiting the vegetation and DBH classes, which is considered an informal way of stratifying the population (Rolecek et al., 2007). 


\section{Tree selection}

Forty trees were used for the study. Sampling error were minimized by grouping plants into DBH classes $(2-10 \mathrm{~cm}, 15-20 \mathrm{~cm}, 21-30 \mathrm{~cm}$ and $31-50 \mathrm{~cm})$. Trees were placed in the immediate delineated quadrat plot of $20 \times 20 \mathrm{~m}$ and all individuals DBH classes were measured with a caliper.

\section{Statistical analyses}

Data were analyzed using one-way analysis of variance (ANOVA) with a confidence level of 0.05 to test the statistical significance. R-software, version 3.2.2 (R Foundation for Statistical Computing, Vienna, Austria) was used for all analyses and ggplot2 package was used for graphing.

Before the equations were established, scatter plots were used to see whether the relationship between independent and dependent variables was linear. Furthermore, several allometric relationships were tested. The independent variables included $\mathrm{DBH}$, height, and local wood density, whereas the dependent variable was the total dry aboveground biomass of the study species (TAGB). Because the data exhibited heteroscedasticity, we used a linear regression analysis.

Model comparison and selection were based on adjusted coefficients of determination, residual standard error, and the penalized likelihood criterion AIC Burnham and Anderson, 2002. The expression of AIC as a criterion for model selection was $\mathrm{AIC}=-2 \ln L+2 p$, where $L$ is the likelihood of the fitted model and $p$ is the total number of parameters in the model.

\section{Nondestructive biomass measurement}

Fresh biomass was divided into two parts for measurements: trimmed fresh biomass and untrimmed fresh biomass. Tree architectures were divided into different architectural elements for ease of analysis, as trimmed branches, untrimmed small branches, untrimmed large branches and trunks for measurement and analysis (FAO, 2012; Picard et al., 2012). Trunks and large branches were not trimmed only small branches were removed. Fresh biomass of small untrimmed branches was calculated from their basal circumference and a biomass table. 
Fresh biomass of large untrimmed branches and trunk calculated from volume and density measurements. Tree sections cuts were considered to be cylindrical, and density was considered to be the identical in all compartments of the tree. Fresh biomass of the trimmed branches was weighed in the field (FAO, 2012; Picard et al., 2012).

(A)

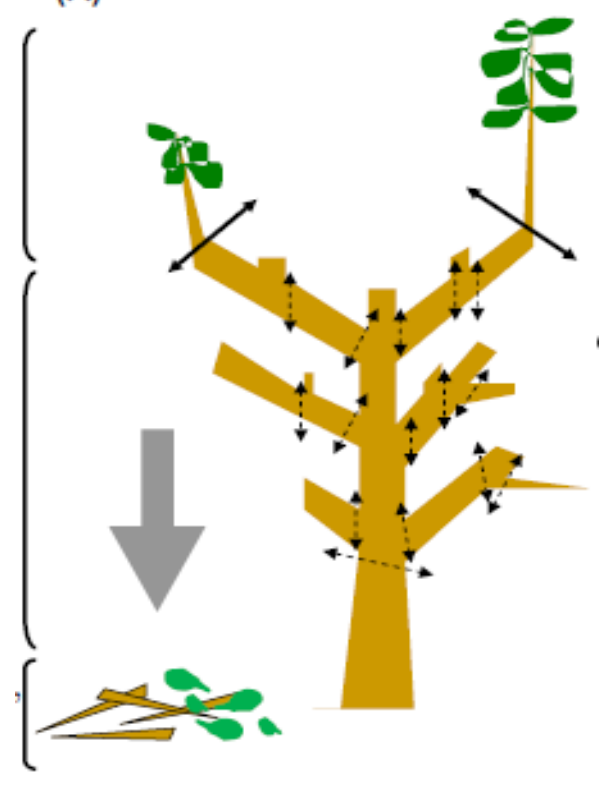

(B)

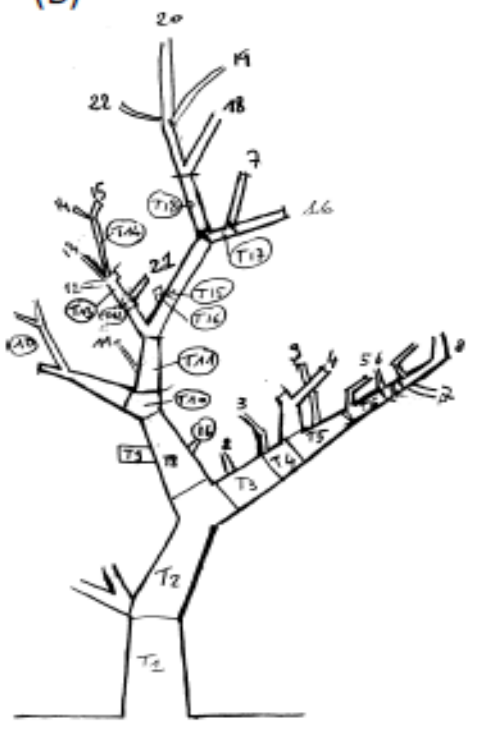

Fig.2.Determination of total fresh biomass. (A) Separation and measurement of trimmed and untrimmed biomass. (B) Numbering of sections and branches measured on the trimmed tree.

\section{Trimmed fresh biomass measurement}

Two secondary branches per plant were removed. Trunk mass was estimated from serial measurements of height, diameter and section volume using a parabolic estimation of trunk shape; these estimates were then used to develop whole-tree allometric equation (Table1). The diameter at the base of each branch to be trimmed was measured using a caliper, then branches were trimmed in compliance with local practices using a machete. Then the leaves were separated from the trimmed branches. Fresh leaves $(B)$ and wood from the trimmed branches $\left(B_{\mathrm{TFW}}\right)$ were weighed separately in the field. Random subsamples of the leaves from the trimmed branches were then weighed $\left(B_{\text {subFL }}\right.$, in $\left.\mathrm{g}\right)$. Similarly, an aliquot of the wood at random from the trimmed branches were taken without debarking and measured for its fresh mass $\left(B_{\text {subFL, }}\right.$ in $\left.\mathrm{g}\right)$ in the field, immediately after cutting (Eqs.1-4). 


\section{Untrimmed fresh biomass}

Untrimmed biomass was measured indirectly. The different branches in the trimmed tree were numbered first. The small untrimmed branches were processed differently from the large branches and the trunk. For the small branches, only basal diameter was measured with caliper. Fresh biomass of small untrimmed branches was calculated from their basal diameter and a model developed from the trimmed branches biomass and their basal diameter (Eq.5-9).

The biomass of the trunk and large branches was estimated from measurements of trunk and large branches volume $\left(V_{i}\right.$ in $\left.\mathrm{cm}^{3}\right)$ and mean wood density $\left(\rho\right.$ in $\left.\mathrm{g} \mathrm{cm}^{-3}\right)$. The volume $V_{i}$ of each section $i$ was obtained by measuring its diameter and its length. Sections about $1 \mathrm{~m}$ long were preferred to consider diameter variations along the length of the trunk and large branches (Eq.6). Wood specific gravity/density was defined as the oven-dried mass of wood sample $\left(101^{\circ} \mathrm{C}-105^{\circ} \mathrm{C}\right)$ divided by the green volume of the sample, which is an important predictor of $A_{\mathrm{BG}}$ (Baker et al., 2004). The green volume of the sample was measured in the field by water displacement and the value of oven-dried wood mass was used to determine mean wood density or wood specific gravity.

\section{Calculations}

The dry biomass of the tree was obtained as a sum of the trimmed dry biomass and the untrimmed dry biomass (FAO, 2012):

$B_{\text {dry }}=B_{\text {trimmed dry }}+B_{\text {untrimmed dry. }}$ (Eq.1)

\section{Calculating trimmed biomass}

From the fresh biomass $B$ of the fresh wood subsample and the dry biomass B subsample of the dry wood, calculated as above, the moisture content of the wood including bark was calculated as (FAO 2012):

$$
X_{\text {wood }}=\frac{B_{\text {dry wood subsample }}}{B_{\text {fresh wood subsample }}} .(\text { Eq.2) }
$$


Similarly, the moisture content of the leaves of the fresh biomass $B$ of the subsample was obtained from the fresh leaf of the leaf subsample and its dry biomass $B$ ofthe subsample of dry leaf was calculated as (FAO, 2012):

$\mathrm{X}_{\text {leaf }}=\frac{\mathrm{B}_{\text {dry leaf subsample }}}{\mathrm{B}_{\text {fresh leaf subsample }}}$

Trimmed dry biomass was then calculated as:

$B_{\text {trimmed dry wood }}=B_{\text {trimmed fresh wood }} X_{\text {wood }}+B_{\text {trimmed fresh leaf }} X_{\text {leaf }}$, (Eq.4)

where $B_{\text {trimmed fresh leaf }}$ is the fresh biomass of the leaves stripped from the trimmed branches and $B_{\text {trimmed fresh wood }}$ is the fresh biomass of the wood in the trimmed branches.

\section{Calculating untrimmed biomass}

Two calculations were required to calculate the dry biomass of the untrimmed part (i.e. that is still standing): one for the small branches, the other for the large branches and the trunk. The untrimmed biomass was the sum of the two results (FAO, 2012).

$B_{\text {untrimmed dry }}=B_{\text {untrimmed dry branch }}+B_{\text {dry section. }}$ (Eq.5)

According to a previously published method (FAO, 2012; Picard et al., 2012), each section $i$ of the trunk and the large branches may be treated as a cylinder to calculate volume using Smalian's formula (FAO, 2012):

$V_{i}=\frac{\pi}{8} \operatorname{Li}\left(D_{1 i}^{2}+D_{2 i}^{2}\right),($ Eq.6)

where $V_{i}$ is the volume of the section, Li its length, and $D_{1 i}$ and $\mathrm{D}_{2 i}$ are the diameters of the two extremities of section $i$.

The dry biomass of the large branches and trunk is the product of mean wood density and total volume of the large branches and trunk (FAO, 2012):

$B_{\text {dry section }}=\bar{\rho} \sum_{i} V_{i}$. (Eq.7)

where mean wood density is calculated as

$\rho=\frac{B_{\text {dry wood subsample }}}{V_{\text {fresh wood subsample }}}$. (Eq.8) 
The dry biomass of the untrimmed small branches was calculated using a model between dry biomass and basal diameter. This model was established by following the same procedure as for the development of an allometric model (FAO, 2012). Linear type equations are often used:

$B_{\text {dry branch }}=a+b D$. (Eq.9)

Using a model of this type, the dry biomass of the untrimmed branches is:

$B_{\text {untrimmed dry branch }}=\sum_{J}(a+D J)$, (Eq.10)

where the sum was all the untrimmed small branches and $D_{J}$ is the basal diameter of the branch $J$ and $a$ and $b$ are model parameters (intercept and slope, respectively).

\section{Estimation of belowground biomass}

Belowground biomass estimation is much more difficult and time-consuming than estimating aboveground biomass (Geider et al.,2001). According to MacDicken (1997), the standard method is estimating belowground biomass $\left(B_{\mathrm{GB}}\right)$ as $20 \%$ of aboveground tree biomass $\left(A_{\mathrm{GB}}\right)$ : $B_{G B}=0.2 A_{\mathrm{GB}}$ (Eq.11).

\section{Result and Discussion}

All estimates of fresh and dry biomass and oven dried moisture content $(X)$ of each tree component of Bersama abyssinica, Cupressus lusitanica, Maytenus arbutifolia, and Rhamnus staddo are given in Table 1.

Table.1. Biomass and moisture content $(X)$ for tree components of study species.

\begin{tabular}{lllllll}
\hline Tree component & $\boldsymbol{N}$ & Maximum & Minimum & Range & Total & Mean \\
\hline Bersama abyssinica & & & & & & \\
\hline Fresh wood mass (mg) & 8 & 2100 & 500 & 1600 & 12,700 & 1587.50 \\
Dry wood mass (mg) & 8 & 979.09 & 233.12 & 745.97 & 5921.19 & 740.15 \\
$X$ wood & 8 & 0.563 & 0.209 & 0.354 & 4.58 & 0.572
\end{tabular}




$\begin{array}{lllllll}\text { Fresh leaf mass (mg) } & 8 & 800 & 200 & 500 & 4500 & 562.50 \\ \text { Oven dry leaf mass (mg) } & 8 & 272.79 & 68.19 & 204.6 & 1534.45 & 191.81 \\ X \text { leaf } & 8 & 0.638 & 0.242 & 0.396 & 4.092 & 0.511 \\ \text { Trimmed dry biomass (mg) } & 8 & 1251.89 & 318.37 & 933.52 & 7455.64 & 931.95\end{array}$

\section{Cupressus lusitanica}

\begin{tabular}{lllllll}
\hline Fresh wood mass (mg) & 12 & 3500 & 1300 & 2200 & 28700 & 1700 \\
Oven dry wood mass (mg) & 12 & 1744.05 & 724.66 & 1019.36 & 13497.5 & 2052.79 \\
$X$ wood & 12 & 0.657 & 0.329 & 0.327 & 5.7546 & 0.479 \\
Fresh leaf mass (mg) & 12 & 3000 & 900 & 2100 & 28700 & 2391.67 \\
Oven dry leaf mass (mg) & 12 & 1560.9 & 355.6 & 1205.3 & 9200.55 & 766.71 \\
$X$ leaf & 12 & 0.6331 & 0.254 & 0.3791 & 5.411 & 0.450 \\
Trimmed dry biomass (mg) & 12 & 2965.45 & 1130.04 & 1835.41 & 22698.05 & 3299.44 \\
\hline Maytenus arbutifolia & & & & & & \\
\hline Fresh wood mass (mg) & 12 & 1900 & 600 & 1300 & 12400 & 1033.33 \\
Oven dry wood mass (mg) & 12 & 1000 & 315.82 & 684.18 & 6526.94 & 543.92 \\
$X$ wood & 12 & 0.686 & 0.222 & 0.464 & 6.15 & 0.513 \\
Fresh leaf mass (mg) & 12 & 600 & 200 & 400 & 4650 & 387.5 \\
& 12 & 216.6 & 72.2 & 144.4 & 1678.65 & 139.89 \\
Oven dry leaf mass (mg) & 12 & 0.630 & 0.223 & 0.407 & 4.132 & 0.344 \\
$X$ leaf & 12 & 1216.69 & 388.02 & 828.67 & 8205.59 & 683.79 \\
Trimmed dry biomass (mg) & & & & &
\end{tabular}

Rhamnus staddo

\begin{tabular}{lllllll}
\hline Fresh wood mass (mg) & 8 & 1000 & 400 & 600 & 5800 & 725 \\
Oven dry wood mass (mg) & 8 & 537.96 & 215.18 & 322.78 & 3120.77 & 390.02 \\
$X$ wood & 8 & 0.698 & 0.357 & 0.341 & 4.22 & 0.528 \\
Fresh leaf mass (mg) & 8 & 400 & 100 & 300 & 1800 & 454.98 \\
Oven dry leaf mass (mg) & 8 & 115.49 & 28.87 & 86.62 & 519.74 & 64.96 \\
$X$ leaf & 8 & 0.408 & 0.222 & 0.186 & 2.309 & 0.289 \\
Trimmed dry biomass (mg) & 8 & 653.45 & 272.93 & 380.52 & 3639.88 & 454.98
\end{tabular}

$N$, number of trees 


\section{Untrimmed biomass}

Dry biomass of large branches and trunks $\left(\boldsymbol{B}_{\mathrm{dry}}\right.$ section $)$

Calculated estimates for the untrimmed biomass components for trees of Bersama abyssinica, Cupressus lusitanica, Maytenus arbutifolia, and Rhamnus staddo are given inTable2.

Table.2. Untrimmed biomass components $(\mathrm{kg})$ for each tree species.

\begin{tabular}{lllllll}
\hline $\begin{array}{l}\text { Tree biomass } \\
\text { component }\end{array}$ & $\boldsymbol{N}$ & Maximum & Minimum & Range & Total & Mean \\
\hline Bersama abyssinica & & & & & & \\
\hline Dry section (kg) & 8 & 6.07 & 0.452 & 5.62 & 32.56 & 4.07 \\
Dry branch (kg) & 8 & 4.95 & 0.970 & 3.980 & 35.19 & 4.39 \\
Untrimmed biomass & 8 & 7.40 & 2.97 & 4.43 & 67.75 & 8.47 \\
$(\mathrm{~kg})$ & & & & & &
\end{tabular}

\section{Cupressus lusitanica}

\begin{tabular}{|c|c|c|c|c|c|c|}
\hline Dry section $(\mathrm{kg})$ & 12 & 608.06 & 49.94 & 558.12 & 3292.31 & 274.36 \\
\hline Dry branch (kg) & 12 & 89.81 & 17.66 & 72.15 & 559.22 & 46.60 \\
\hline $\begin{array}{l}\text { Untrimmed biomass } \\
\text { (kg) }\end{array}$ & 12 & 680.61 & 76.84 & 603.78 & 3851.53 & 320.96 \\
\hline \multicolumn{7}{|l|}{ Maytenus arbutifolia } \\
\hline Dry section $(\mathrm{kg})$ & 12 & 27.23 & 0.805 & 26.43 & 118.02 & 9.84 \\
\hline Dry branch $(\mathrm{kg})$ & 12 & 5.65 & 2.26 & 3.39 & 45.05 & 3.76 \\
\hline $\begin{array}{l}\text { Untrimmed biomass } \\
(\mathrm{kg})\end{array}$ & 12 & 32.87 & 3.06 & 29.81 & 163.08 & 13.59 \\
\hline \multicolumn{7}{|l|}{ Rhamnus staddo } \\
\hline Dry section $(\mathrm{kg})$ & 8 & 22.04 & 0.45 & 21.59 & 64.96 & 8.12 \\
\hline Dry branch $(\mathrm{kg})$ & 8 & 3.29 & 1.27 & 2.02 & 16.45 & 2.07 \\
\hline $\begin{array}{l}\text { Untrimmed biomass } \\
(\mathrm{kg})\end{array}$ & 8 & 23.84 & 1.71 & 22.13 & 81.41 & 10.18 \\
\hline
\end{tabular}

$N$, number of trees 
After computing the dry section, dry branch, untrimmed biomass and trimmed biomass, the total biomass was determined $\left(A_{\mathrm{GB}}+B_{\mathrm{GB}}\right)$. Aboveground biomass is the sum of all biomass components Table 3.

Developed models for untrimmed small branches had the following statistical results, the $p$-value of Model-1 for Bersama abyssinica relating the basal diameter and trimmed dry biomass was 0.00294 for the predictor variable, basal diameter, indicating a strong

Table.3. Aboveground $\left(A_{\mathrm{GB}}\right)$, belowground $\left(B_{\mathrm{GB}}\right)$, and total biomass of each tree species

\begin{tabular}{lllllll}
\hline Tree component & $N$ & Maximum & Minimum & Range & Total & Mean \\
\hline Bersama abyssinica & & & & & & \\
\hline$A_{\mathrm{GB}}(\mathrm{kg})$ & 8 & 8.36 & 3.31 & 5.05 & 75.21 & 9.40 \\
$B_{\mathrm{GB}}(\mathrm{kg})$ & 8 & 1.67 & 0.66 & 1.01 & 15.04 & 1.88 \\
Total biomass (kg) & 8 & 10.04 & 3.97 & 6.07 & 90.25 & 11.28 \\
\hline Cupressus lusitanica & & & & & & \\
\hline$A_{\mathrm{GB}}(\mathrm{kg})$ & 12 & 682.78 & 78.05 & 604.73 & 3874.23 & 322.85 \\
$B_{\text {GB }}$ & 12 & 36.56 & 15.61 & 20.95 & 774.85 & 64.57 \\
Total biomass (kg) & 12 & 819.33 & 93.65 & 725.68 & 4649.08 & 387.42 \\
\hline Maytenus arbutifolia & & & & & & 14.27 \\
\hline$A_{\mathrm{GB}}(\mathrm{kg})$ & 12 & 33.55 & 3.51 & 30.04 & 171.29 & 2.85 \\
$B_{\mathrm{GB}}(\mathrm{kg})$ & 12 & 34.26 & 0.70 & 33.56 & 34.26 & 17.25 \\
Total biomass (kg) & 12 & 40.26 & 4.21 & 36.05 & 205.55 & \\
\hline Rhamnus staddo & & & & & & \\
\hline$A_{\mathrm{GB}}(\mathrm{kg})$ & 8 & 24.20 & 2.09 & 22.11 & 84.45 & 10.56 \\
$B_{\mathrm{GB}}(\mathrm{kg})$ & 8 & 4.84 & 0.42 & 4.42 & 16.89 & 2.11 \\
Total biomass (kg) & 8 & 29.04 & 2.51 & 26.53 & 101.34 & 12.67 \\
\hline$N_{\text {number of trees }}$ & & & & & & \\
\hline
\end{tabular}

$N$, number of trees

statistically significant correlation between basal diameter and trimmed dry biomass at $95 \%$ confidence interval. The accuracy of Model-1, given by $R^{2}(0.7038)$, shows that $70.21 \%$ of the variation of the output variable, trimmed dry biomass, is explained by variation of the input 
variable, basal diameter. The $R^{2}$ for Model-2 for Cupressus lusitanica is $0.6039(p=0.00294)$ (Table5).

Table.4. Allometric equations for untrimmed small branches for each studied tree species

\begin{tabular}{lllll}
\hline Species & Intercept & Slope & $\boldsymbol{R}^{\mathbf{2}}$ & $\boldsymbol{P}$ \\
\cline { 2 - 5 } Bersama abyssinica (Model-1) & 338.4 & 504.9 & 0.6039 & 0.00294 \\
Cupressus lusitanica (Model-2) & 179.9 & 654.1 & 0.7021 & 0.00294 \\
Maytenus arbutifolia (Model-3) & 359.13 & 126.49 & 0.6087 & 0.00276 \\
Rhamnus staddo (Model-4) & 66.65 & & & \\
\hline
\end{tabular}

The $R^{2}$ for Maytenus arbutifolia was $0.6087(p=0.002756)$ and 0.6278 for Rhamnus staddo $(p=$ 0.001904). As estimated by the linear regression model, the $A_{\mathrm{GB}}$ based on the basal diameter of the small untrimmed branches measured in the field was $559.22 \mathrm{~kg}$ for Cupressus lusitanica (mean $46.60 \mathrm{~kg}$, range $72.15 \mathrm{~kg}$ ). For Bersama abyssinica, total $A_{\mathrm{GB}}$ was $35.19 \mathrm{~kg}$ (mean $2.93 \mathrm{~kg}$, range $3.980 \mathrm{~kg}$ ) and likewise, Maytenus arbutifolia, total $A_{\mathrm{GB}}$ was $45.05 \mathrm{~kg}$ (mean $3.76 \mathrm{~kg}$, range 3.39 $\mathrm{kg}$ ) and $16.45 \mathrm{~kg}$ for Rhamnus staddo (mean $2.07 \mathrm{~kg}$, range $2.02 \mathrm{~kg}$ ).

In the present study models developed using DBH as the sole explanatory variable provided a satisfactory estimation, since the total variation explained by the relationship was high $\left(R^{2}\right)$ (Table.5). This indicates that DBH alone is a robust indicator of aboveground biomass, which implies the variability of biomass of trees in forest landscape is largely explained by variability in DBH. It is in agreement with previous reports (Basukie et al. 2009; Zianis and Mencuccini, 2004).

Moreover, DBH alone is a good estimator of biomass especially in terms of the multiple trade-offs between accuracy, cost and practicality of the measurements because DBH is always included in 

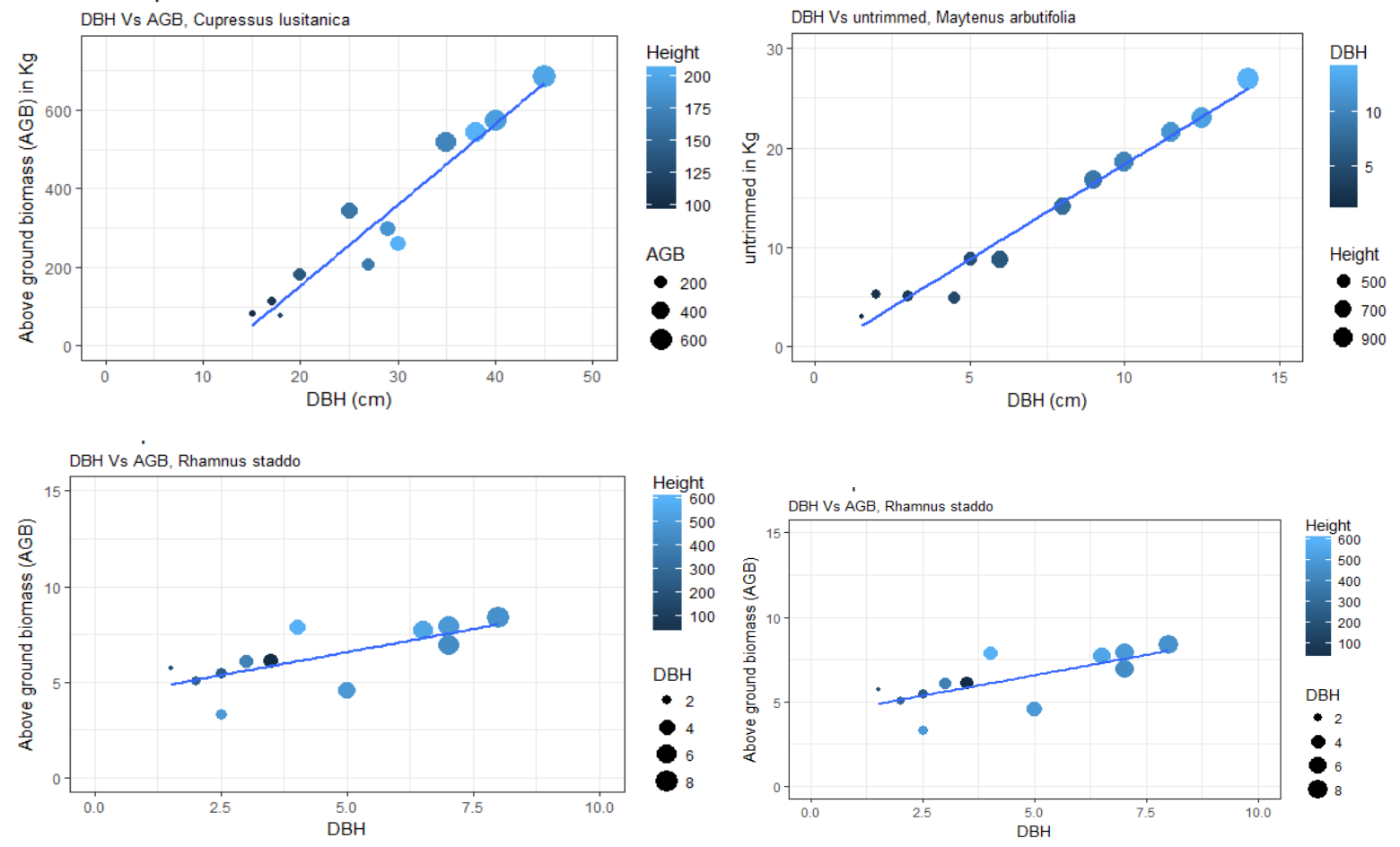

Fig.3.Scatter plot of aboveground biomass $(\mathrm{kg})$ per DBH $(\mathrm{cm})$ class sorted by height $(\mathrm{m}), \mathrm{DBH}$ (cm), and $A_{\mathrm{GB}}$.
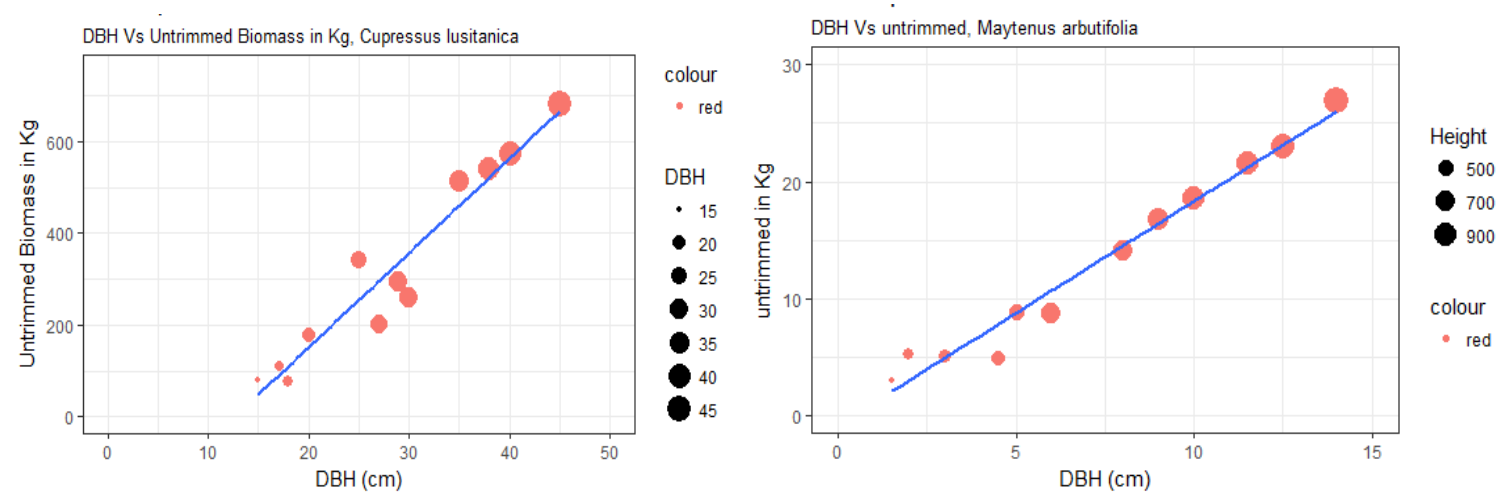

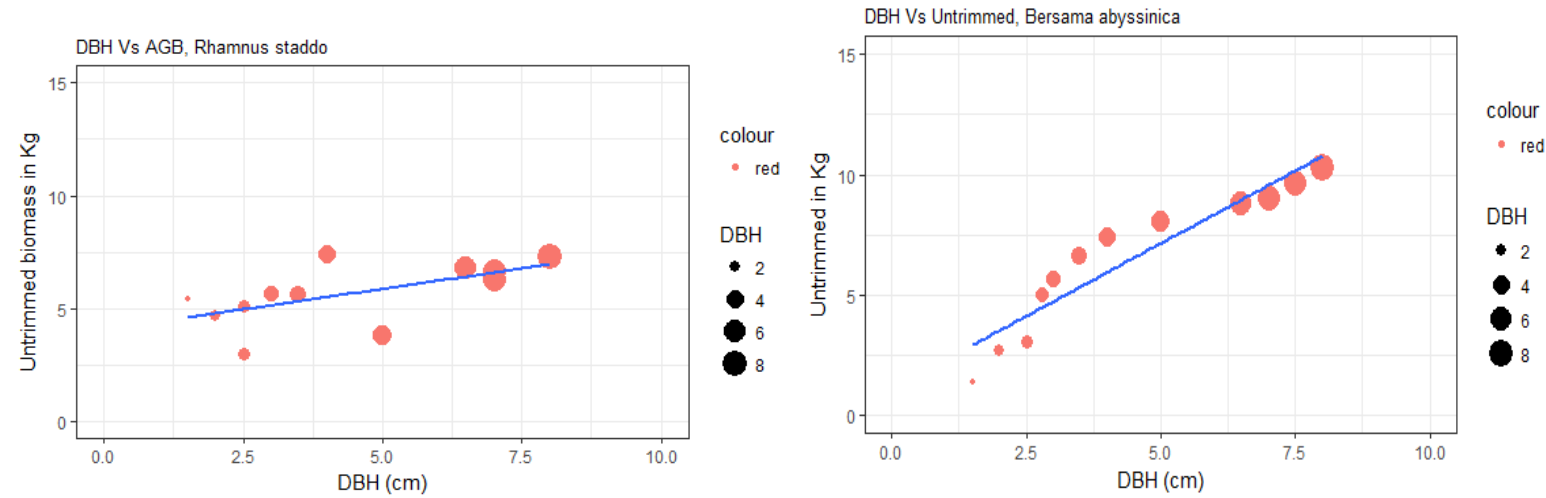

Fig.4.Scatter plot of untrimmed biomass $(\mathrm{kg})$ versus DBH $(\mathrm{cm})$ of the study species sorted by height $(\mathrm{m})$ and $\mathrm{DBH}(\mathrm{cm})$.

Local wood specific gravity is one of the principal estimators of $A_{\mathrm{GB}}$, particularly when a broad range of vegetation type is considered. Most researchers have developed allometric equations through wood density/wood specific gravity as representative factor for the studied species (Chave et al.,2004, 2014; Henry et al., 2010). Here, we analyzed the branches from the trimmed section to obtain a local mean wood density for the study species $\left(0.3584 \mathrm{~g} / \mathrm{cm}^{3}\right.$ for Bersama abyssinica, $0.5313 \mathrm{~g} / \mathrm{cm}^{3}$ for Cupressus lusitanica, $0.4437 \mathrm{~g} / \mathrm{cm}^{3}$ for Maytenus arbutifolia and $0.4382 \mathrm{~g} / \mathrm{cm}^{3}$ for Rhamnus staddo (Table5).

Table.5. Statistical indicators, $R^{2}$, adjusted (Adj.) $R^{2}$, and p-values for models

\begin{tabular}{lllll} 
Model & Allometric equation & $R^{2}$ & Adj. $R^{2}$ & $p$-value \\
\hline Model-5 & $A_{\mathrm{GB}}=-258.30+20.57(\mathrm{DBH})$ & 0.9279 & 0.8207 & $4.939 \times 10^{-7}$ \\
Model-6 & $A_{\mathrm{GB}}=-1.1407+2.1262(\mathrm{DBH})$ & 0.9416 & 0.9058 & $1.7 \times 10^{-5}$ \\
& & & & \\
Model-7 & $A_{\mathrm{GB}}=4.1542+0.4830(\mathrm{DBH})$ & 0.5952 & 0.4448 & 0.01065 \\
Model-8 & $A_{\mathrm{GB}}=2.4031+1.9747(\mathrm{DBH})$ & 0.913 & 0.7985 & 0.0002131 \\
Model-9 & $A_{\mathrm{GB}}=-143.492+26.387(\mathrm{DBH})-16.93(\mathrm{H})$ & 0.9488 & 0.8474 & $1.56 \times 10^{-6}$ \\
Model-10 & $A_{\mathrm{GB}}=-3.33+0.3656(\mathrm{DBH})+0.413(\mathrm{H})$ & 0.7961 & 0.7508 & 0.0007807
\end{tabular}




\begin{tabular}{clccc} 
Model-11 & $A_{\mathrm{GB}}=-1.246+2.1(\mathrm{DBH})+0.044(\mathrm{H})$ & 0.9416 & 0.9286 & $2.809 \times 10^{-06}$ \\
Model-12 & $A_{\mathrm{GB}}=-2.25+3.220(\mathrm{DBH})-1.356(\mathrm{H})$ & 0.9253 & 0.8954 & 0.001526 \\
Model-13 & $\begin{array}{l}A_{\mathrm{GB}}=-193.359+25.869(\mathrm{DBH})-15.727(\mathrm{H})+ \\
90.952(\rho)\end{array}$ & 0.9500 & 0.9312 & $1.509 \times 10^{-5}$ \\
Model-14 & $A_{\mathrm{GB}}=9.996+0.51799(\mathrm{DBH})-0.044(\mathrm{H})-17.37(\rho)$ & 0.8383 & 0.7777 & 0.001568 \\
& & & & \\
Model-15 & $A_{\mathrm{GB}}=5.538+1.9545(\mathrm{DBH})+0.316(\mathrm{H})+8.01(\rho)$ & 0.9421 & 0.9204 & $2.706 \times 10^{-5}$ \\
Model-16 & $A_{\mathrm{GB}}=-2.193+3.234(\mathrm{DBH})-1.378(\mathrm{H})-2.557(\rho)$ & 0.9253 & 0.8693 & 0.01019 \\
\hline
\end{tabular}

Models7, 10, and 14 are for Bersama abyssinica; Models5, 9, and 13 for Cupressus lusitanica, Models6, 11, and 15 for Maytenus arbutifolia, and Models8, 12, and 16 for Rhamnus staddo.

In addition, if total tree height is available, allometric models usually yield less-biased estimates. However, tree height has often been ignored in biomass estimation and carbon-accounting programs (Chave et al. 2014). We found that including total tree height, measured serially and local wood density, improved biomass predictions when compared to using DBH alone as is evident from the increment in the adjusted coefficient of determination for each species $(0.9312,0.7777$, 0.9204, and 0.8693) (Table5). These findings corroborate with those reported by Isthmus of Panama (Bastein-Henri, et al. 2010) and the humid lowlands of Costa Rica (Cole and Ewel, 2006).

\section{Model selection}

The residual standard errors (RSE) for Bersama abyssinicamodels-7, 10, 14show very low values $1.15,0.69,0.73$, respectively, indicating good fit of the models or a very minimal error value for $A_{\mathrm{GB}}$ estimation. Although based on the AIC value, which penalizes parameter-rich models, we can say that model-7 is parsimonious with one variable, but any of the three models could provide a very good proximal estimation depending on the availability of forest inventory data such as height and density. Similarly, models for Cupressus lusitanica had close RSE values $(52.23,54.72,58.76)$ for models-5, 9 , and 13 , but despite this closeness, their adjusted $R^{2}$ values had better capacity as 
explanatory variables in the model, indicating that model-13 could be used for better estimation of aboveground biomass for the study species depending on the availability of forest inventory data.

Maytenus arbutifolia, all the three models (models-6, 11, 15) had RSE values of 2.34, 2.61, and 2.47 , respectively, and the adjusted $\mathrm{R}^{2}$ gave slight improvement, and the AIC penalized model15 more than model- 6 and model-11 because it included three independent variables. Regardless, the model's application for estimating for the species is not limited in the presence of sufficient inventory data, and this study established local densities for the study species. However, in the absence of data for height, model- 6 could effectively be used to estimate aboveground biomass.

Table.6. Residual standard error (RSE), adjusted $R^{2}$ and Akaike information criterion (AIC)

\begin{tabular}{|c|c|c|c|c|}
\hline Species & Models & RSE & $\begin{array}{l}\text { Adjusted } \\
R^{2}\end{array}$ & AIC \\
\hline & $A_{\mathrm{GB}}=-258.30+20.57(\mathrm{DBH})$ & 58.76 & 0.8207 & 133.54 \\
\hline & $A_{G B}=-143.492+26.387(\mathrm{DBH})-16.93(\mathrm{H})$ & 52.23 & 0.8474 & 135.63 \\
\hline \multicolumn{5}{|l|}{ Cupressus } \\
\hline lusitanica & $A_{G B}=-193.359+25.869(\mathrm{DBH})-15.727(\mathrm{H})+90.952(\rho)$ & 54.72 & 0.9312 & 135.3 \\
\hline \multirow{3}{*}{$\begin{array}{l}\text { Bersama } \\
\text { abyssinica }\end{array}$} & $A_{G B}=4.1542+0.4830(\mathrm{DBH})$ & 1.149 & 0.4448 & 39.57 \\
\hline & $A_{G B}=-3.33+0.3656(\mathrm{DBH})+0.413(\mathrm{H})$ & 0.6882 & 0.7508 & 40.34 \\
\hline & $\mathrm{A}_{\mathrm{GB}}=9.996+0.51799(\mathrm{DBH})-0.044(\mathrm{H})-17.37(\rho)$ & 0.7273 & 0.7777 & 42.35 \\
\hline \multirow{3}{*}{$\begin{array}{l}\text { Maytenus } \\
\text { arbutifolia }\end{array}$} & $A_{G B}=-1.1407+2.1262(\mathrm{DBH})$ & 2.34 & 0.9058 & 58.26 \\
\hline & $A_{G B}=-1.246+2.1(\mathrm{DBH})+0.044(\mathrm{H})$ & 2.466 & 0.9286 & 60.27 \\
\hline & $A_{G B}=5.538+1.9545(\mathrm{DBH})+0.316(\mathrm{H})+8.01(\rho)$ & 2.605 & 0.9204 & 62.16 \\
\hline
\end{tabular}


Rhamnus

staddo

$$
A_{G B}=-2.25+3.220(\mathrm{DBH})-1.356(\mathrm{H})
$$

$2.311 \quad 0.8954$

40.35

$$
A_{G B}=-2.193+3.234(\mathrm{DBH})-1.378(\mathrm{H})-2.557(\rho)
$$

Finally, models developed for Rhamnus staddo, revealed the same pattern, with a low residual standard error $(2.28,2.32,2.58)$, models-8, 12, and 16 and adjusted $R^{2}$ of $0.7985,0.8954$, and 0.8693 (Table5).

The coefficient of determination $\left(\mathrm{R}^{2}\right)$ is used in many biomass studies to evaluate simple linear regression models based on the ability to explain variance of the model compared to the total variance (Chave et al. 2005; Picard et al. 2012; Goodman et al. 2014). However, when developing multiple regression models, it is necessary to check and evaluate $R^{2}$ against the adjusted coefficient of determination to overcome the limits of $R^{2}$, because whenever adding model variables in a regression, the $R^{2}$ is likely to increase by chance alone and thus, be misleading for the interpretation as a goodness of fit. Therefore, in this study the adjusted $R^{2}$ is used as explanatory power of variation in multiple linear regression because it is adjusted for the number of estimators in the model (Lilja 2016). It only increases if the new variable improves the model more than expected by chance. In this study, the adjusted $R^{2}$ has increased for the studied species when adding more predictor variables into regression line. Models developed for Bersama abyssinica (models-7, 10, and 10) resulted an improved adjusted $R^{2}$ of $0.4448,0.7508$, and 0.777 , respectively. Models-5, 9, and 13 for Cupressus lusitanica yielded an adjusted $R^{2}$ of $0.8207,0.8474$, and 0.9312 , respectively. Models-6, 11, and 15 for Maytenus arbutifolia had a value of 0.9058, 0.9208, and 0.9204, and models-8, 12, and 16 for Rhamnus staddo had an adjusted $R^{2}$ of $0.7985,0.8954$, and 0.8693 , respectively.

Comparison of biomass result estimated by models developed in this study against general pantopicals revealed disparity with our findings. It's attributable for reasons such as local wood density and ecological variables specific to the study location. Moreover, linear regression models are 
preferred for simplicity and usually yield the best fit for data. The pan-tropical models were Brown et al. (1989), general equation-1, $\mathrm{AGB}=34.4703-8.0671 \mathrm{DBH}+0.6589 \mathrm{DBH}^{2}$, typically relates tree biomass to $\mathrm{DBH}$ and ignores relevant factors such as tree density and height for estimating biomass. And general equation-1 of Chave et al. (2014) incorporates height and density, and their best performing model is $A_{\mathrm{GB}}=0.0559 \rho D^{2} H$.

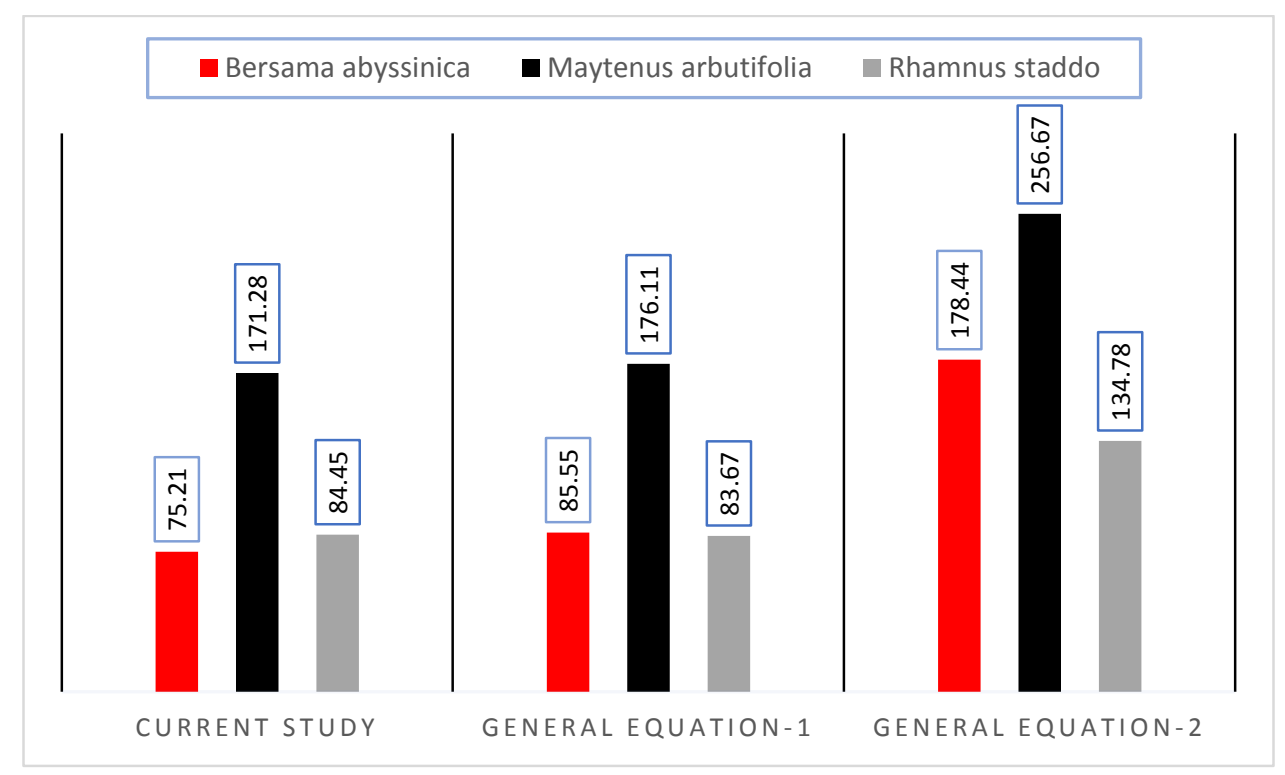

Figure 5. Comparison of biomass estimation models

The total biomass estimated by general equation-1 of Chave et al. (2014), provides an estimate comparable to some in this study; the model estimated comparable values for Maytenus arbutifolia $(176.11 \mathrm{~kg})$ and for Rhamnus staddo $(83.67 \mathrm{~kg})$ and for Bersama abyssinica $(85.55 \mathrm{~kg})$. However, because tree height and DBH for Cupressus lusitanica was estimated as a higher value, and the model overestimated the biomass, predicting $5449.72 \mathrm{~kg}$. 


\section{Conclusion}

Locally developed allometric equations are fundamental for accurate estimation of biomass and/or carbon stock assessment. This study estimated the biomass and developed allometric equations that can be used by researchers, forest managers and/or organizations such as REDD+ to calculate aboveground biomass for estimation of carbon stock of the studied species in Ethiopia. This study also provided locally developed wood density for the study species. The best performing models were $A_{\mathrm{GB}}=9.996+0.518(\mathrm{DBH})-0.044(H)-17.37(\rho)$, model 14 for Bersama abysinica, $A_{\mathrm{GB}}=-193.359+25.869(\mathrm{DBH})-15.727(H)+90.952(\rho)$, model 13, for Cuprussus lusitanica, and $A_{\mathrm{GB}}=5.538+1.9545(\mathrm{DBH})+0.316(H)+8.01(\rho)$, model 15 and for Maytenus arbutifolia, and $A_{\mathrm{GB}}=-2.25+3.220(\mathrm{DBH})-1.356(H)$, model 12 for Rhamnus staddo. 


\section{Acknowledgments}

The authors are thankful to the EgduDistrict Forest Enterprise Office for their permission to carry out study and forestry experts at the district office for their support in field data collection. The authors also extend thanks to Addis Ababa University for the fund released willingly. 


\section{References}

Bastein-Henri, S., Park, A., Ashton, M., Messier, C (2010). Biomass distribution among tropical tree species grown under differing regional climate. Forest Ecology Management: 260(3): 403-410.

Basuki, M., van Laake, P., Skidmore, A., Hussin, Y (2009). Allometric equations for estimating the above-ground biomass in tropical lowland Dipterocarp forests. Forest Ecology and Management 257(8):1684-1694.

Brown, I.F., Martinelli, L.A., Thomas, W.W., Moreira, M.Z. Victoria, R.A. \& Ferreira A.C. (1995). Uncertainty in biomass of Amazonian forest: an example from Rondonia, Brazil. Forest Ecology and Management: 75:157-189.

Brown, S., Gillespie, R., Lugo, E (1989). Biomass estimation methods for tropical forests with applications to forest inventory data. Forest Science 35(4):881-902.

Burnham, P. \& Anderson R., (2002). Multimodal inference: understanding AIC and BIC in model selection. BehavEcolSociobiol: 65:23-35.

Chave, J., Andalo, C., Brown, S., Cairns, A., Chambers, Q., Eamus, D., Fölster, H., Fromard, F., Higuchi, N., Kira, T., Lescure, P., Nelson, W., Ogawa, H., Puig, H., Riéra, B., and Yamakura, $\mathrm{T}$ (2005). Tree allometry and improved estimation of carbon stocks and balance in tropical forests. Oecologia.; 145:87-99.

Chave, J., Condit, R., Aguilar, S., Hernandez, A., Lao, S., Perez, R (2004). Error propagation and scaling for tropical forest biomass estimate. Philosophical Transactions of the Royal Society of London Series B 359: 409-420.

Chave, J., Mechain, M., Burquez, A., Chidumayo, E., Colgan, M., Delitti, W., Duque, A., Eid, T., Fearnside, P., Goodman, R., Henary, M., Yrizar, A., Mugasha, W., Landau, H., Mencuccini, M., Nelson, B., Ngomanda, A., Nogueira, E., Malavassi, E., Pelissier, R., Ploton, P., Ryan, C., Saldarriaga, J., \&Vieilledent, G (2014). Improved allometric models to estimate the aboveground biomass of tropical trees. Global Change Biology: 20:3177-3190.

Cole, T., \&Ewel, J (2006). Allometric equations for four valuable tropical tree species. Forest Ecology Management: 229(1-3):351-360.

Crow, T., andSchlaegel, B.A (1987).Guide to using regression equations for estimating tree biomass. North Journal of Applied Forestry: 5: 5-22. 
Djomo, A., Ibrahima, A., Saborowski, J., Gravenhorst, G (2010). Allometric equations for biomass estimations in Cameroon and pan moist tropical equations including biomass data from Africa. Forest Ecology and Management 260: 1873-1885.

FAO (Food and Agriculture Organization) (2012). Manual for building tree volume and biomass allometric equations: from field measurement to estimation. Rome, Italy. Pp51-78.

Fayolle, A., Doucet, J.L., Gillet, J.F., Bourland, N., Lejeune, P (2013). Tree allometry in Central Africa: testing the validity of pantropical multi-species allometric equations for estimating biomass and carbon stocks. Forest Ecology and Management 305:29-37.

Fearnside, P (1997). Wood density for estimating forest biomass in Brazilian Amazonia. Forest Ecology and Management 90(1):59-87.

Geider, J. R., Delucia, H. E., Falkowsk, G. P.,Finzi, C. A., Grime, P. J., Grace, J., Kana, M. T., Roche, J. (2001). Primary productivity of planet earth: biological determinants and physical constraints in terrestrial and aquatic habitats. Global Change biology7: 849-882.

Henry, M., Besnard, A., Asante, W. A., Eshun, J., Adu-Bredu, S., Valentini, R., Saint-Andre, L. (2010).Wood density, phytomass variations within and among trees, and allometric equations in a tropical rainforest of Africa.Forest Ecology and Management, 260(8): 1375-1388.

Henry, M., Picard, N., Trotta, C., Manlay, R.J., Valentini, R., Bernoux, M., Saint-André, L (2011). Estimating Tree Biomass of Sub-Saharan African Forests: Review of available allometric equations .Silva Fennica45: 477-569.

Houghton, A (2001). The annual net flux of carbon to the atmosphere form changes in land used 1850-1990. Tellus B 51:298-13.

Houghton, R.A (2003). Why estimates of the terrestrial carbon balance so different? Glob. Change Biol: 9:500-509.

Kairo, J., Bosire, J., Langat, J., Kirui, B., Koedam, N (2009). Allometry and biomass distribution in replanted mangrove plantations at Gazi Bay, Kenya. Aquatic Conservation: Marine and Fresh Water Ecosystem 19:63-69.

Ketterings, Q., Coe, R., Noordwijk, M., Ambagau, Y., Palm, C (2001). Reducing uncertainty in the use of allometric biomass equations for predicting aboveground tree biomass in mixed secondary forests. Forest Ecology and Management 146(1):199-209.

Lilja D.J. (2016) Linear Regression Using R: An Introduction to Data Modeling. University of Minnesota Libraries Publishing, Minnesota, USA, pp-1-3. 
MacDicken, K. G. (1997). A Guide to Monitoring Carbon Storage in Forestry and Agro-forestry Projects.In:Forest Carbon Monitoring Program.Winrock International Institute for Agricultural Development, Arlington, Virginia, pp-1-46.

Nath, A., Das, G., Das, A (2009). Above ground standing biomass and carbon storage in village bamboos in north east India. Biomass and Bioenergy 33:1188-1196.

Navar, J (2002). Allometric equations for tree species and carbon stocks for forests of north western Mexico. Forest Ecology and Management 257(2):427-434.

Nogueira, M., Nelson, W., Fearnside, M., Franca, B., Oliveira, D. (2008). Tree height in Brazil's " 'arc of deforestation"': shorter trees in South and Southwest Amazonia imply lower biomass. Forest Ecology and Management 255:2963-2972.

Picard, N., Saint André, L., Henry, M. (2012). Manual for building tree allometric equations: from the field to the estimation, Food and Agriculture Organization of the United Nations, Centre de CoopérationInternationaleen RechercheAgronomique, Roma, Italy, pp-1-190.

Rolecek, J., Chytry, M., Hajek, M., Lvoncik, S., Lubomir, T (2007). Sampling design in large scale vegetation studies: Do not sacrifice ecological thinking to statistical purism. Folia Geobotanica 42:199-208.

Russell, C. (1983). Nutrient cycling and productivity of native and plantation forest at JariFlorestal, Para, Brazil Ph.D. thesis, University of Georgia, Athens, Brazil, pp-76-89.

Slik, F., Bernard, S., Breman, C., Beek, M., Salim, A., Sheil, D (2008). Wood density as a conservation tool: quantification of disturbance and identification of conservation priority areas in tropical forests. Conservation Biology 22(5):1299-1308.

Zianis, D., Mencuccini, M (2004). On simplifying allometric analyses of forest biomass. Forest Ecology and Management 187:311-332. 
Nondestructive allometric model to estimate aboveground biomass: an alternative approach to generic pan-tropical models 